\title{
Characteristic of Tuber spp. localities in natural stands with emphasis on plant species composition
}

\author{
Dorota Hilszczańska1*, Aleksandra Rosa-Gruszecka², Hanna Szmidla² \\ ${ }^{1}$ Department of Forest Ecology, Forest Research Institute, Braci Leśnej 3, Sękocin Stary, 05-090 Raszyn, Poland \\ ${ }_{2}^{2}$ Department of Forest Protection, Forest Research Institute, Braci Leśnej 3, Sękocin Stary, 05-090 Raszyn, Poland
}

\section{Abstract}

Fungi belonging to the genus Tuber establish ectomycorrhizal symbioses with shrubs, trees and some herbaceous plants. Some Tuber species, for example, T. melanosporum, T. magnatum, T. aestivum are economically important because they produce edible fruiting bodies with a distinctive taste and flavor. Our concept of truffle ecophysiology is dominated by the symbiosis with deciduous hosts, such as: Quercus spp., Fagus sylvatica, Castanea sativa, Corylus spp., Carpinus betulus, Ostrya carpinifolia, Betula verrucosa, and Tilia spp., whereas the real range of hosts in nature seems to be much wider. Moreover, interactions between Tuber mycelium and plant community could be more complex than just forming the ectomycorrhizal symbiosis. Here we show our inventory of plants and soils at six truffle' sites in the southern part of Poland (Nida Basin and Przedbórz Upland). The aim of this study was to widen our understanding of ecological factors affecting Tuber spp., in the context of pioneering stage of research on truffles in Poland. We hope our findings will have a practical application and will help to choose suitable soils for truffle orchards.

Keywords: hypogeous fungi; truffles; forest stands, plant community; soil parameters

\section{Introduction}

Truffles are prized fungi due to their taste and aroma. They are hypogeous and belong to Pezizales, a large group of ectomycorrhizal fungi growing in symbiosis with the roots of several vascular plant species (angiosperms and gymnosperms). Among the different

\footnotetext{
* Corresponding author. Email: d.hilszczanska@ibles.waw.pl

Handling Editor: Maria Rudawska
} 
species of truffles, Tuber magnatum (white truffle), Tuber melanosporum (black truffle), Tuber aestivum (summer truffle) and Tuber macrosporum Vittad. (the smooth black truffle) are most valued and expensive.

The first two species mentioned earlier are mainly confined to Mediterranean and some South Europe countries (Bulgaria and Serbia) while T. aestivum is widely distributed throughout Europe [1,2]. The fungus forms ectomycorrhizal symbioses with many different species, including Corylus avellana, Quercus robur, Fagus sylvatica, Tilia cordata and Pinus nigra. This truffle species prefers calcareous soils with $\mathrm{pH}$ levels near or above 7-8, although it occurs in beech woods on lime-deficient soils in the United Kingdom [3]. According to Czerniecki [4] some species of truffles were eaten by Polish nobility in the author's time, so it seems likely that T. aestivum sites have existed in Poland for at least 300 years. Some reports of attempts to cultivate truffles are present in late 19th century literature [5-7]. In the last decade, new distributional data for T. aestivum and other truffle species have been reported from Poland [8,9] and neighboring countries, Slovakia [10], the Czech Republic [11] and Germany [12].

Tuber macrosporum is another truffle species highly appreciated as delicacies, which has been found recently in Poland [9]. This species is common in central Italy while it has been reported as very rare in the Czech Republic, France, Hungary, Romania, Serbia, Switzerland, Ukraine and the United Kingdom [13]. Two years ago the species was found in Germany where they were considered extinct [12]. Tuber macrosporum forms ectomycorrhizae with C. avellana, C. colurna and Quercus species, for example: Q. petraea, Q. pubescens, Q. robur and Q. suber [15]. Coniferous species, especially Pinus sylvestris can also form ectomycorrhizae with T. macrosporum [15].

Currently, due to growing demand for truffles, the establishment of truffle orchards in Poland is in progress. Some areas are especially conducive to truffle cultivation due to similarities of soil and/or climatic conditions to that of French and Italian localities. Truffle productivity and phenology is driven by interrelated biotic and abiotic factors, such as: climate, physiology, pedology and vegetation [14]. The data presented here have a practical application for those who are interested in truffle cultivation. The knowledge of truffles' soil requirements and the plant species sharing the same ecological niche should be useful in choosing a suitable location for truffle orchards.

\section{Material and methods}

The study was conducted in Nida Basin and Przedbórz Upland, the southern part of Poland. The environmental characteristic of the natural forest stands is given in Tab. 1.

The truffle localities at the stands were found using the trained truffle dogs in collaboration with Researchers from Agricultural University in Nitra. Inventories were made in 2012-2014. Yield of truffles is given in Tab. 2. Species of truffles were identified on the basis of microscopic features and compared to the criteria by Granetti et al. [15]. Samples of fruiting bodies were also taken for molecular identification. The DNA sequences are deposited in Genbank NCBI (accession numbers to their sequences are as follow: T. maculatum-KJ524540.1, T. excavatum-KJ524535.1, T. macrosporum-KJ524532.1, T. aestivum-KJ524527.1, T. rufum-KC330221). 
Tab. 1 Environmental characteristic of Tuber spp. sites.

\begin{tabular}{|c|c|c|c|c|c|c|}
\hline Plot No. & Site & Location & Bedrock & Altitude (m) & Vegetation & Tuber species \\
\hline 1 & $\mathrm{M}$ & Nida Basin & marlstone & $250-252$ & $\begin{array}{l}\text { Broadleaved forest } \\
\text { with Quercus robur, } \\
\text { Tilia cordata, Carpinus } \\
\text { betulus, Fagus sylvatica } \\
\text { and Corylus avellana }\end{array}$ & $\begin{array}{l}\text { T. aestivum } \\
\text { T. excavatum } \\
\text { T. maculatum } \\
\text { T. rufum }\end{array}$ \\
\hline 2 & SA & Nida Basin & marlstone & $311-314$ & $\begin{array}{l}\text { Oak forest with Quercus } \\
\text { petraea, Carpinus } \\
\text { betulus, Cerasus avium } \\
\text { and Corylus avellana }\end{array}$ & $\begin{array}{l}\text { T. aestivum } \\
\text { T. excavatum } \\
\text { T. rufum }\end{array}$ \\
\hline 3 & WR & Nida Basin & marlstone & $290-296$ & $\begin{array}{l}\text { Broadleaved forest } \\
\text { with Quercus petraea, } \\
\text { Acer pseudoplatanus, } \\
\text { Carpinus betulus } \\
\text { and Corylus avellana }\end{array}$ & $\begin{array}{l}\text { T. aestivum } \\
\text { T. excavatum }\end{array}$ \\
\hline 4 & GR & Nida Basin & gypsium & $254-261$ & $\begin{array}{l}\text { Oak forest with Quercus } \\
\text { robur and Carpinus } \\
\text { betulus }\end{array}$ & $\begin{array}{l}\text { T. aestivum } \\
\text { T. excavatum }\end{array}$ \\
\hline 5 & $\mathrm{PR}$ & $\begin{array}{l}\text { Przedbórz } \\
\text { Upland }\end{array}$ & $\begin{array}{l}\text { Jurassic } \\
\text { limestone }\end{array}$ & $312-325$ & $\begin{array}{l}\text { Beech forest with Fagus } \\
\text { sylvatica }\end{array}$ & T. aestivum \\
\hline 6 & NW & Nida Basin & $\begin{array}{l}\text { marly } \\
\text { limestone }\end{array}$ & $227-228$ & $\begin{array}{l}\text { Thicket with Carpinus } \\
\text { betulus, Acer campestre } \\
\text { and Populus tremula }\end{array}$ & $\begin{array}{l}\text { T. aestivum } \\
\text { T. macrosporum } \\
\text { T. maculatum } \\
\text { T. excavatum }\end{array}$ \\
\hline
\end{tabular}

Over three years of study, the mean annual precipitation was $600 \mathrm{~mm}$ and the annual mean temperature for the same period was $8.0^{\circ} \mathrm{C}$. At each of the six localities the sampling site $\left(100 \mathrm{~m}^{2}\right)$ was established. The vegetation at each site was surveyed in order to determine whether there was any indicator species for T. aestivum and/or co-occurring truffle species. The host-plants as well as the plants of forest floor whose biotopic preferences coincided with those of Tuber spp. are summarized in Tab. 3. The soil was sampled at the central part of each site by removing the litter and vegetation layers and then collecting approximately $0.5 \mathrm{~kg}$ of soil down to a depth of $0-30 \mathrm{~cm}$, depending on the rockiness of the soil. The soil analyses were performed by the Polish Centre for Accreditation (No. AB740).

The soil pH in water (Tab. 3) and essential nutrient contents were measured according to ISO 10390 [17] and PB-14ed.2 of 1 January 2010 [using inductively coupled argonplasma spectrometry following mineralization in chloric (VII) acid], respectively. The percentages of $\mathrm{N}$ and $\mathrm{C}$ were analyzed according to ISO13878 [17] and ISO 10694 [18]. The soil texture was evaluated on the basis of occurrence of three particle size fractions: $<2 \mu \mathrm{m}$ (clay), 2-63 $\mu \mathrm{m}$ (silt), and 63-2000 $\mu \mathrm{m}$ (sand) [19]. 


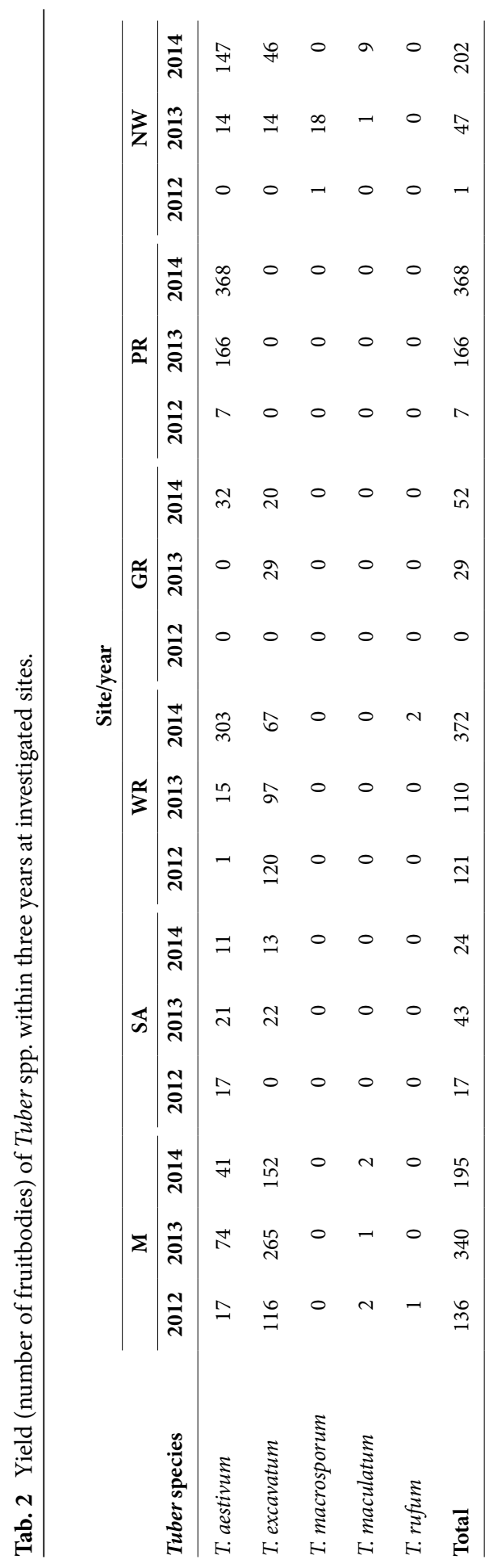


Tab. 3 Overview of the soil properties at the Tuber aestivum sites.

\begin{tabular}{|c|c|c|c|c|c|c|c|c|}
\hline \multirow[b]{2}{*}{ Measured parameter } & \multicolumn{6}{|c|}{ Site } & \multirow[b]{2}{*}{ Mean $\pm S D$} & \multirow[b]{2}{*}{ Range } \\
\hline & $\mathbf{M}$ & SA & WR & GR & PR & NW & & \\
\hline \multicolumn{9}{|c|}{ Soil particle size fractions $(\%)$} \\
\hline Clay & 33.10 & 40.23 & 23.30 & 17.11 & 22.69 & 14.42 & $25.14 \pm 9.80$ & $14.42-40.23$ \\
\hline Silt & 55.83 & 47.03 & 61.70 & 37.32 & 28.33 & 22.17 & $42.06 \pm 15.53$ & $22.17-61.70$ \\
\hline Sand & 11.07 & 12.74 & 15.00 & 45.57 & 48.98 & 63.41 & $32.80 \pm 22.60$ & $11.07-63.41$ \\
\hline \multicolumn{9}{|c|}{ Chemical characteristics } \\
\hline $\mathrm{pH}\left(\mathrm{H}_{2} \mathrm{O}\right)$ & 7.2 & 7.1 & 7.0 & 7.3 & 7.2 & 7.5 & $7.22 \pm 0.17$ & $7.00-7.5$ \\
\hline $\mathrm{CaCO}_{3}$ total $(\%)$ & 6.02 & 1.17 & 31.52 & 1.81 & 6.04 & 4.04 & $8.43 \pm 11.49$ & $1.17-31.52$ \\
\hline $\mathrm{Ca}(\%)$ & 34.44 & 15.64 & 42.80 & 14.99 & - & 19.77 & $25.53 \pm 12.45$ & $14.99-42.80$ \\
\hline C total $(\%)$ & 10.09 & 5.165 & 5.625 & 5.38 & 5.98 & 2.108 & $5.72 \pm 2.56$ & $2.11-10.09$ \\
\hline C organic (\%) & 9.364 & 5.024 & 4.791 & 5.16 & 5.25 & 1.623 & $5.20 \pm 2.46$ & $1.62-9.36$ \\
\hline $\mathrm{N}$ total (\%) & 0.764 & 0.356 & 0.41 & 0.46 & 0.371 & 0.138 & $0.42 \pm 0.20$ & $0.14-0.76$ \\
\hline $\mathrm{C} / \mathrm{N}$ & 13.2 & 14.5 & 13.7 & 11.7 & 16.12 & 15.30 & $14.09 \pm 1.58$ & $11.70-16.12$ \\
\hline
\end{tabular}

\section{Results}

Our inventory revealed five species from Tuber genus: T. aestivum, T. macrosporum, T. rufum, T. excavatum and T. maculatum. The geographical names of the site where the species were found will be available for further research, but not for publication. Publishing site names could lead to reckless prospecting for truffles, resulting in damage to the surrounding flora. At five out of six sites T. aestivum was accompanied by other truffle species (Tab. 1, Tab. 2). The stands are mixed broadleaved forest, with diverse plants of forest floor. The stand PR is rather poor in forest floor vegetation, and the only hostspecies is Fagus sylvatica. Only species of T. aestivum were found there. Soils from the investigated localities are of Rendzic type. Their chemical properties are given in Tab. 3. According to the atlas of forest soils of Poland [21], the bedrock of the regions consists of Cretaceous marlstone, limestone, gypsum and of Miocene clays and sands. Various Quaternary deposits cover more than three quarters of the region. The analyzed soils varied from "heavy" (up to $40.23 \%$ clay) to "light" (up to $63.41 \%$ sand) - Tab. 3 .

The highest diversity of trees and shrubs at investigated sites were in the stand depicted as WR. This stand was the richest in regard to herbaceous plants and mosses. The lowest richness of forest floor plants and mosses was observed at the stand NW. Plants associated with Tuber species are given in Tab. 4.

Number of tree and shrub host-species differ from two to six in all stands. Coniferous species were represented by Pinus sylvestris and its presence was noted only at stand WR.

One hundred and five species of forest floor plants were identified, among them, three orchids' species - putative host-species of truffles. They were present in all but one stand (NW). At this site the lowest number of plants of the forest floor was observed. In the stand PR no species representing mosses were noted. 
Tab. 4 Plant species recorded on the studied plots of Tuber spp. sites known (in bold font) and potential host plants are distinguished in boxes.

\begin{tabular}{|c|c|c|c|c|c|c|}
\hline Tree and shrubs & $\mathbf{M}$ & SA & WR & GR & PR & NW \\
\hline Abies alba & & + & & & & \\
\hline Acer campestre & & & & & & + \\
\hline Acer platanoides & & + & & & + & \\
\hline Acer pseudoplatanus & + & & + & + & & \\
\hline Carpinus betulus & + & + & + & + & & + \\
\hline Cerasus avium & + & + & + & + & & \\
\hline Cornus sanguinea & + & + & + & & + & + \\
\hline Corylus avellana & + & + & + & + & & \\
\hline Crataegus monogyna & + & + & + & + & + & + \\
\hline Daphne mezereum & & + & & & & \\
\hline Euonymus europeus & + & & + & + & & + \\
\hline Euonymus verrucosus & + & + & & & + & \\
\hline Fagus sylvatica & + & & + & + & + & \\
\hline Frangula alnus & & & + & & & \\
\hline Fraxinus excelsior & + & + & + & & & + \\
\hline Juniperus comunis & & & & & & + \\
\hline Ligustrum vulgare & & & & & & + \\
\hline Lonicera xylosteum & + & + & + & & & \\
\hline Malus sylvestris & & & & + & & + \\
\hline Padus avium & & & & + & & \\
\hline Padus serotina & & & & + & & \\
\hline Pinus sylvestris & & & + & & & \\
\hline Populus tremula & & & & & & + \\
\hline Prunus spinosa & & & + & & + & + \\
\hline Pyrus communis & & & & + & + & + \\
\hline Quercus petraea & + & + & + & + & & \\
\hline Quercus robur & + & + & + & + & & + \\
\hline Quercus rubra & & + & & & & \\
\hline Rosa canina & + & + & + & & + & \\
\hline Sambucus nigra & + & + & + & + & & \\
\hline Sorbus aucuparia & & + & + & & & \\
\hline Tilia cordata & + & & & & & \\
\hline Ulmus glabra & & & & + & & \\
\hline Ulmus minor & & & + & & & \\
\hline Viburnum opulus & + & + & + & + & + & + \\
\hline Host species / all species & $6 / 17$ & $4 / 18$ & $6 / 20$ & $5 / 16$ & $1 / 9$ & $3 / 14$ \\
\hline Plants of the forest floor & $\mathbf{M}$ & SA & WR & GR & PR & NW \\
\hline \multicolumn{7}{|l|}{ Herbaceous plants } \\
\hline Actaea spicata & & & + & & & \\
\hline Adoxa moschatellina & + & & + & & & \\
\hline Aegopodium podagraria & + & & + & + & & + \\
\hline Agrostis capillaris & + & + & + & + & + & + \\
\hline
\end{tabular}


Tab. 4 (continued)

Ajuga reptans

Anemone nemorosa

Asarum europaeum

Astragalus glycyphyllos

Athyrium filix-femina

Brachypodium sylvaticum

Calamagrostis epigejos

Campanula persicifolia

Campanula rapunculoides

Campanula rotundifolia

Campanula trachelium

Carex digitata

Carex echinata

Carex hirta

Carex sylvatica

Carex umbrosa

Cephalanthera damasonium

Chaerophyllum aromaticum

Chamaecytisus ratisbonensis

Cimicifuga europaea

Cirsium arvense

Clinopodium vulgare

Convallaria majalis

Cruciata glabra

Cypripedium calceolus

Dactylis polygama

Dryopteris carthusiana

Dryopteris filix-mas

Epipactis helleborine

Fallopia dumetorum

Festuca gigantea

Festuca heterophylla

Fragaria vesca

Galeobdolon luteum

Galeopsis pubescens

Galium aparine

Galium boreale

Galium mollugo

Galium odoratum

Galium schultesii

Galium sylvaticum

Geranium robertianium

Geum urbanum

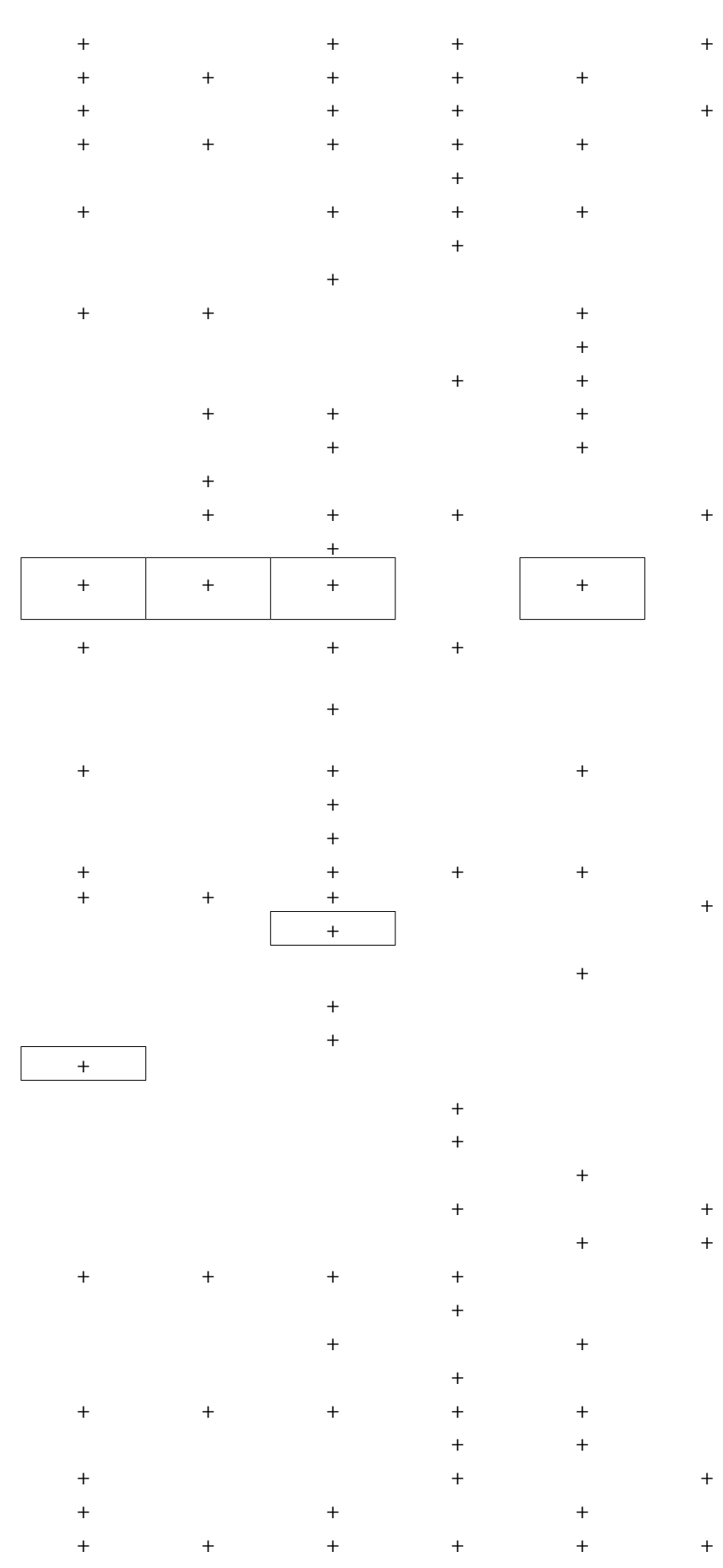


Tab. 4 (continued)

Glechoma hederacea

Hepatica nobilis

Hieracium murorum

Holcus mollis

Impatiens parviflora

Lapsana communis

Laserpitium latifolium

Lathyrus nigier

Lathyrus vernus

Lilium martagon

Luzula pilosa

Lysimachia nemorum

Maianthemum bifolium

Melica nutans

Melampyrum nemorosum

Melittis melissophyllum

Milium effusum

Moehringia trinervia

Mycelis muralis

Oxalis acetosella

Paris quadrifolia

Pimpinella saxifraga

Plantago major

Polygonatum multiflorum

Primula elatior

Prunella vulgaris

Pulmonaria obscura

Ranunculus cassubicus

Ranunculus lanuginosus

Rubus idaeus

Rubus saxatilis

Rubus nessensis

Rubus pedemontanus

Sanicula europaea

Solidago virgaurea

Sonchus oleraceus

Stachys sylvatica

Stellaria holostea

Taraxacum officinale

Torilis japonica

Urtica dioica

Veronica chamaedrys

Vicia sepium

Vincetoxicum hirundinaria

Viola mirabilis

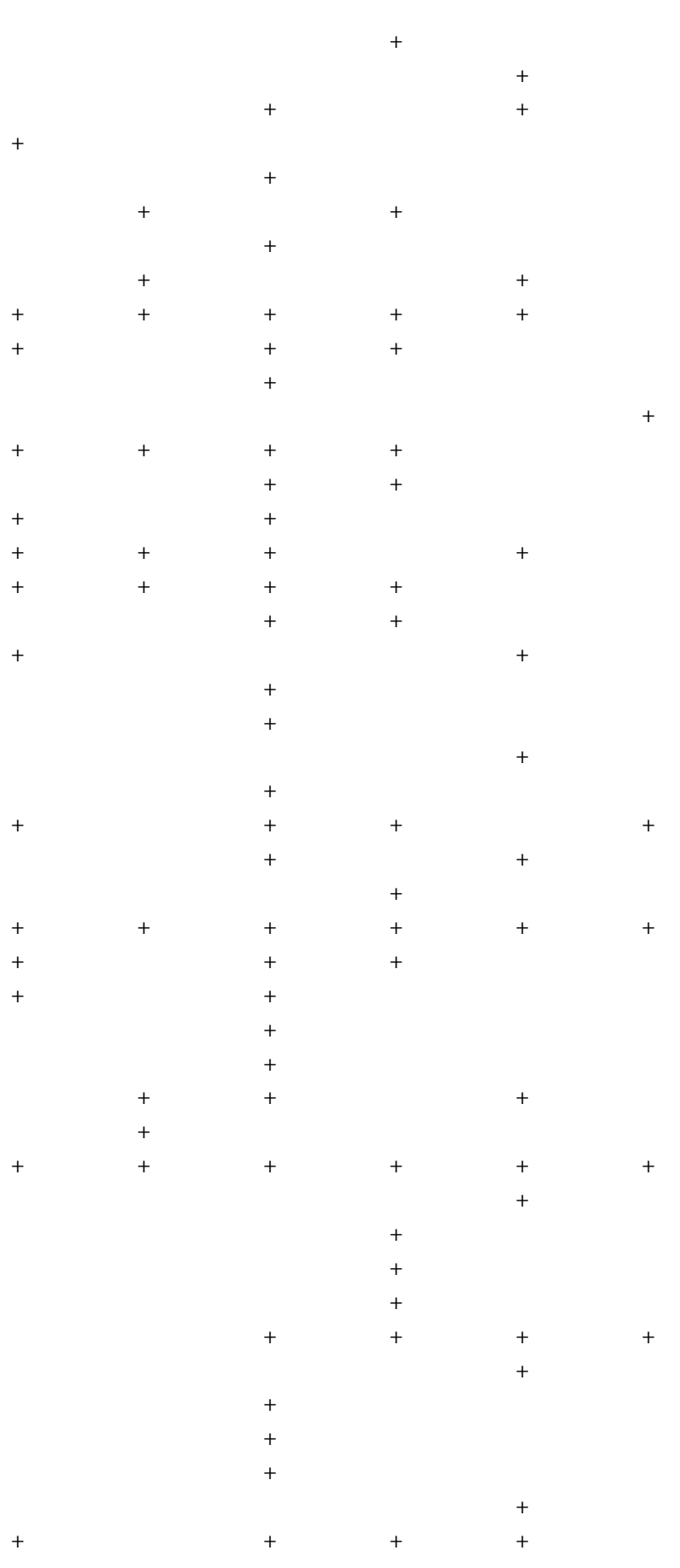


Tab. 4 (continued)

\begin{tabular}{|c|c|c|c|c|c|c|}
\hline $\begin{array}{l}\text { Viola reichenbachiana } \\
\text { Mosses }\end{array}$ & + & + & + & + & + & + \\
\hline Atrichum undulatum & & & + & & & \\
\hline Brachythecium velutinum & + & + & & & & \\
\hline Eurhynchium angustiret & + & & & & & \\
\hline Eurhynchium striatum & & & + & + & & \\
\hline Fissidens taxifolius & & & & & & + \\
\hline Hypnum cupressiforme & & + & & & & \\
\hline Mnium undulatum & & & & & & + \\
\hline Mnium elatum & & & + & & & \\
\hline Oxyrrhynchium hians & + & & + & & & + \\
\hline $\begin{array}{l}\text { Pseudoscleropodium } \\
\text { purum }\end{array}$ & & & + & & & \\
\hline Rhytidiadelphus triquetrus & & & + & & & \\
\hline Host species / all species & $2 / 38$ & $1 / 25$ & $2 / 66$ & $0 / 43$ & $1 / 37$ & $0 / 17$ \\
\hline
\end{tabular}

\section{Discussion}

Truffles mainly depend on mutual relationships with angiosperm hosts including Quercus spp., Fagus sylvatica and Corylus avellana [21,22]. However some species such as Tuber puberulum Berk. \& Broome and Tuber borchii Vittad. prefer gymnosperm hosts [23]. Host specificity plays an important role but is not clearly defined for most wildlife associations [24]. Our previous inventory suggested that, in Poland, the deciduous host species are highly important to the occurrence of Tuber species [9]. For example, the greatest abundance of T. aestivum fruiting bodies was found in forests where species such as: Quercus robur, Corylus avellana, Fagus sylvatica, Carpinus betulus and Tilia cordata occur together [8]. Our findings presented in this work changed this opinion slightly, since at PR site the only host-species tree is beech and, moreover, we obtained here the great yield of T. aestivum within the last three years. Fructification of T. astivum at plots where $P$. sylvestris and/or P. tremula is present, are confirmation of findings by Stobbe et al. [12]. The authors mentioned Picea abies, Abies alba, Ulmus spp. and Populus spp. as potential hosts. Some of the above-cited studies reported the reduction of vegetation due to the presence of Tuber spp. According to Gryndler and co-authors [25] this could be the result of negative effect of the Tuber mycelium on the growth of some of the non-host plants. There can be also direct effects (both positive and negative) of the non-host plants on the Tuber mycelium. Thus, the interaction between Tuber mycelium and plant community could be more complex than just forming the ectomycorrhizal symbiosis. Physico-chemical analysis of soils on our sites revealed that the soil texture is moderately varied, ranging from silty-clay to clayey-silt and more rarely silty, silty-sandy or clayey. The analyzed soils varied from sandy clay (up to $40.23 \%$ clay) to sandy loam up to $63.41 \%$ sand. The latter soils are generally thought to be less favorable for truffle fructification, however even excessively sandy soils can support truffle development 
if they are sufficiently rich in calcium [26,27]. Our results showed that soils with the higher content of calcium, in the form of $\mathrm{Ca}$ cations and $\mathrm{CaCO}_{3}$, were conducive to the higher fructification of T. aestivum. All investigated soils were poor in readily degradable nitrogen, a $\mathrm{C} / \mathrm{N}$ ratio was above ten and varied from 13.2 to 16.12 . This means that the development of mycorrhizae could not have been limited.

Development of truffles depends on $\mathrm{pH}$ as well. According to Chevalier and Frochot [28] truffles can grow in soils with $\mathrm{pH}$ range 6.8 to 8.0. However it cannot be claimed that $\mathrm{pH} 7.5$ is the optimal level to maintain the highest level of mycorrhization on host plants roots [29]. Although we did not investigate the mycorrhiza structure, our observation made on truffles' fructification showed that T. aestivum can form fruitbodies even in soils with $\mathrm{pH}$ 7. The results might be really important for truffle growers, especially in countries where the area of calcareous soils is limited.

The role of soil properties other than $\mathrm{pH}$ and carbonate content for truffle fructification is still poorly understood, so further work is needed. Establishing of truffle orchards in our country has been started in a previous decade and is still in progress. We have to take into account the numerous, interrelated biotic and abiotic factors driving truffle productivity and phenology from a holistic perspective [14]. Otherwise, we can derive some contradicted conclusion, for example, the greatest abundance of T. aestivum fruiting bodies was found in forests where all of host-species occurred together [8]. However, at the site indicated as PR, where the only host-species tree is beech, we found a great abundance of T. aestivum fruit bodies within the last three years (2012-2014). Therefore we have to be cautious with the statement that a greater diversity of host-species occurs with a higher yield of truffles. Presently, we would rather be of the opinion that each of the investigated sites is unique. As long as we do not have the climatic, soil and vegetation data combined together our conclusions will remain preliminary.

\section{Acknowledgments}

The authors thank two anonymous reviewers for useful comments improving the manuscript. This work was due to grant financed by State Forest Holding No. OR-2717/19/11.

\section{Authors' contributions}

The following declarations about authors' contributions to the research have been made: design of the study: DH, ARG; study data interpretation, manuscript preparation, literature review: DH, ARG, HS.

\section{References}

1. Pacioni G, Comandini O. Tuber. In: Cairney JWG, Chambers SM, editors. Ectomycorrhizal fungi. Key genera in profile. Berlin: Springer; 1999. p. 163-186. http://dx.doi.org/10.1007/978-3-662-06827-4

2. Chevalier G. The truffle of Europe (Tuber aestivum): geographic limits, ecology and possibility of cultivation. Osterr Z Pilzkd. 2010;19:249-259.

3. Pegler DN, Spooner BM, Young TWK. British truffles. A revision of British hypogeous fungi. Kew: Royal Botanical Gardens; 1993.

4. Czerniecki S. Compedium Ferculorum albo zebranie potraw. Polish first cookbook. Kraków: Collegium Columbinum, Szedlowie Jerzy i Mikołaj; 1682.

5. Aleksandrowicz J, Błoński F. Encyklopedia rolnicza. Warszawa; 1894.

6. Gawarecki Z. Trufle i ich sztuczne pielęgnowanie. Lwów: Red. "Bartnika Postępowego"; 1895.

7. Spausta W. Trufle. Sylwan. 1897;15(6,7):161-167,201-208. 
8. Hilszczańska D, Sierota Z, Palenzona M. New Tuber species found in Poland. Mycorrhiza. 2008;18(4):223226. http://dx.doi.org/10.1007/s00572-008-0175-4

9. Hilszczańska, D, Rosa-Gruszecka A, Sikora K, Szmidla H. First report of Tuber macrosporum occurrence in Poland. Scientific Research and Essays. 2013;7(23):1096-1099. http://dx.doi.org/10.5897/SRE2013.5529

10. Gazo J, Miko M, Chevalier G. First results of inventory research on economically important species of truffles (Tuber) in the Tribec Mountains. Acta Fytotechnica et Zootechnica. 2005;8(3):66-71.

11. Streiblova E, Gryndlerova H, Valda S, Gryndler M. Tuber aestivum - hypogeous fungus neglected in the Czech Republic. A review. Czech Mycol. 2010;61(2):163-173.

12. Stobbe U, Büntgen U, Sproll L, Tegel W, Egli S, Fink S. Spatial distribution and ecological variation of re-discovered German truffle habitats. Fungal Ecol. 2012;5(5):591-99. http://dx.doi.org/10.1016/j. funeco.2012.02.001

13. Hall I, Brown G, Zambonelli A. Taming the truffle. The history, lore, and science of the ultimate mushroom. Portland, OR: Timber Press; 2007.

14. Büntgen U, Egli, S, Camarero JJ, Fischer EM, Stobbe U, Kauserud H, et. al., 2012. Drought-induced decline in Mediterranean truffle harvest. Nat Clim Chang. 2012;2(12):827-829. http://dx.doi.org/10.1038/nclimate1733

15. Granetti B, de Angelis A, Materozzi G. Umbria terra di tartufi. Regione Umbria: Assessorato regionale agricoltura, foreste, caccia e pesca; 2005.

16. ISO 10390. Soil Quality. Determination of pH. Geneva: International Organization for Standardization; 1997.

17. ISO 13878. Soil Quality. Determination of total nitrogen content by dry combustion ("elemental analysis"). Geneva; International Organization for Standardization; 2002.

18. ISO 10694. Soil Quality. Determination of organic and total carbon after dry combustion ("elementary analysis"). Geneva: International Organization for Standardization; 2002.

19. ISO 11277. 2005. Soil quality. Determination of particle size distribution in mineral soil material. Method by sieving and sedimentation. Geneva: International Organization for Standardization; 2005.

20. Brożek S, Zwydak M. Atlas gleb leśnych Polski. Warszawa: CILP; 2003.

21. Chevalier G, Frochot H. Ecology and possibility of culture in Europe of the Burgundy truffle (Tuber uncinatum Chatin). Agric Ecosyst Environ. 1989;28:71-73. http://dx.doi.org/10.1016/0167-8809(90)90016-7

22. Smith SE, Read DJ. Mycorrhizal symbiosis. 2nd edn. San Diego, CA: Academic Press; 1997.

23. Bonito GM, Gryganskyi AP, Trappe JM, Vilgalys R. A global meta-analysis of Tuber ITS rDNA sequences: species diversity, host associations, and long distance dispersal. Mol Ecol. 2010;19:4994-5008. http:// dx.doi.org/10.1111/j.1365-294X.2010.04855.x

24. Bruns TD, Bidartondo MI, Taylor L. Host specificity in ectomycorrhizal communities: what do the exceptions tell us? Integr Comp Biol. 2002;42:352-359. http://dx.doi.org/10.1093/icb/42.2.352

25. Gryndler M, Černá, L, Bukovská P, Hršelová, H, Jansa, J. Tuber aestivum association with non-host roots. Mycorrhiza. 2014;24(8):603-610. http://dx.doi.org/10.1007/s00572-014-0580-9

26. Chevalier G. Europe, a continent with high potential for the cultivation of the Burgundy truffle (Tuber aestivum/uncinatum). Acta Mycol. 2012;47(2):127-132. http://dx.doi.org/10.5586/am.2012.014

27. Chevalier G, Sourzat P. Soils and techniques for cultivating Tuber melanosporum and Tuber aestivum in Europe. In: Zambonelli A, Bonito GM, editors. Edible ectomycorrhizal mushrooms. Berlin: Springer; 2012. p. 163-190. (Soil Biology, vol 34). http://dx.doi.org/10.1007/978-3-642-33823-6_10

28. Chevalier G, Frochot H. La truffe de Bourgogne. Paris: Pétrarque; 1997.

29. Thomas PW. The role of $\mathrm{pH}$ in Tuber aestivum syn. uncinatum mycorrhiza development within commercial orchards. Acta Mycol. 2012;47(2):161-167. http://dx.doi.org/10.5586/am.2012.019 